\title{
Alcohol and Atherosclerosis*
}

\author{
PROTASIO L. DALUZ and SILMARA R. COIMBRA \\ Instituto do Coração (INCOR) USP, Unidade de Aterosclerose, \\ Rua Eneas de Carvalho Aguiar, 44 - 05403-000 São Paulo, SP, Brazil \\ Manuscript received on August 25, 2000; accepted for publication on August 30, 2000; \\ contributed by PROTÁsIo L. DA LUz**
}

\begin{abstract}
Atherosclerosis is manifested as coronary artery disease (CAD), ischemic stroke and peripheral vascular disease. Moderate alcohol consumption has been associated with reduction of CAD complications. Apparently, red wine offers more benefits than any other kind of drinks, probably due to flavonoids.

Alcohol alters lipoproteins and the coagulation system. The flavonoids induce vascular relaxation by mechanisms that are both dependent and independent of nitric oxide, inhibits many of the cellular reactions associated with atherosclerosis and inflammation, such as endothelial expression of vascular adhesion molecules and release of cytokines from polymorphonuclear leukocytes.

Hypertension is also influenced by the alcohol intake. Thus, heavy alcohol intake is almost always associated with systemic hypertension, and hence shall be avoided. In individuals that ingest excess alcohol, there is higher risk of coronary occlusion, arrhythmias, hepatic cirrhosis, upper gastrointestinal cancers, fetal alcohol syndrome, murders, sex crimes, traffic and industrial accidents, robberies, and psychosis. Alcohol is no treatment for atherosclerosis; but it doesn't need to be prohibited for everyone. Thus moderate amounts of alcohol (1-2 drinks/day), especially red wine, may be allowed for those at risk for atherosclerosis complications.
\end{abstract}

Key words: alcohol, coronary heart disease, atherosclerosis, stroke, wine.

\section{INTRODUCTION}

Lately moderate alcohol consumption has been associated with reduction of coronary artery disease (CAD) complications. For instance, in France, CAD prevalence is lower than in several other European countries, although ingestion of saturated fat in the diet is the same. This is called the "French paradox" which has been specifically attributed to red wine consumption. It was also demonstrated in the Lyon Study (Lorgeril et al. 1999), that the Mediterranean diet which includes the ingestion of red wine,

\footnotetext{
*Invited paper

** Member of Academia Brasileira de Ciências

Correspondence to: Protásio Lemos da Luz

E-mail: daluzp@incor.usp.br
}

reduced the incidence of new coronary events by approximately $70 \%$.

The prevalence of the CAD is, at least partly, related to lifestyle; such prevalence increases with saturated fat rich diets, obesity, cigarette smoking, sedentary life, and stress. Genetic components may also interact with environmental factors. Atherosclerosis can be manifested as CAD, ischemic stroke and peripheral vascular disease, and it tends to be progressive.

On the other hand, there is strong evidence that it is possible to slow progression of aterosclerosis, and even induce regression of certain lesions. This was specifically demonstrated with intensive treatment of hipercholesterolemia. Such treatment 
includes therapeutic interventions and changes in lifestyle. These changes are almost always restrictive, and difficult to apply in clinical practice; food restrictions, quitting cigarette smoking and use of therapeutic interventions are good examples of such restrictions.

By contrast alcohol consumption, if beneficial, would be an intervention not restrictive, and even pleasant. In this article we will review evidences relating alcohol and the evolution of atherosclerosis.

\section{EXPERIMENTAL AND CLINICAL EVIDENCES}

The preference for a given beverage varies among social classes; it also varies with dietary habits. Apparently, red wine offers more benefits than any other kind of drinks. Maybe because individuals whose preference is wine, tend to have a better lifestyle, better cardiovascular risk profile, better cultural level and smoke less. International comparisons demonstrate that countries where the wine is the most popular beverage have lower CAD mortality, in comparacion to others that favor other alcoholic beverages.

Moderate alcohol consumption protects against CAD; the relationship is described by a $U$ shaped curve; as it can be appreciated in such a curve, abstainers and those who take more than 2 drinks per day have increased total mortality and non-cardiac deaths, as well as higher blood pressure. On the other hand moderate amounts of alcohol reduce the risk of CAD including mortality, hospitalizations and angina pectoris both in men and women (Marmot \& Brunner 1991, Klatsky et al. 1990, Camargo et al. 1997). Small daily doses seem more protective than the same dose taken in one single ingestion. Moderate alcohol consumption also acts in secondary prevention for those who suffered previous myocardial infarct, reducing new coronary events and mortality.

The Framingham Study, also evaluated the clinical manifestations of CAD in 22 years of follow-up; there was an inverse relationship between alcohol consumption and symptoms of CAD (angina, myocardial infarction, sudden death and death from CAD (Gordon \& Kannel 1983).

In a multicenter study carried out in Hawaii, the protective effect of alcohol in women and asian men, was smaller than in caucasian men. Several casecontrol studies found an inverse association between DAC and alcohol consumption. Fig. 1 illustrates alcohol effects on several studies.

Alcohol is protective in men as well as in women. The Nurses' Health Study, based on data from 87.562 womem, aged 34-59 years and 200 CAD cases found a decreased risk of events in those taking alcoholic beverages, after adjustment for other risk factors (Stampfer et al. 1988).

Experimental studies in animals confirm the protective effect of moderate alcohol consumption and the adverse effect of high doses. For instance, Da Luz and collaborators (da Luz et al. 1999), demonstrated that red wine, as well as non alcoholic wine products, reduced the formation of atherosclerotic plaques significantly in hypercholesterolemic rabbits, despite high blood lipids. In this experience the mechanisms of action of the wine were not clarified. Arteriographic and necropsy studies in humans have also demonstrated anti-atherogenic effect of alcohol.

Similar to $\mathrm{CAD}$, the incidence of ischemic stroke relates to alcohol in a J-shaped curve for cerebral infarct (Wannamethee \& Shaper 1998), but in a lineal type for subarachnoid hemorrhage. Stroke can be caused by atherosclerosis in the carotid or cerebral arteries, due to formation of plaques and thrombus, usually in elderly individuals; there is minor risk in individuals that consume moderate amounts of alcohol, with 20 to $40 \%$ event reduction. Among the participants of the Copenhagen City Heart Study after adjustement for age, sex and smoking, there was smaller risk of stroke with ingestion of wine; beer and distilled beverages had no effect. In the Framingham Study there also was a J-shaped relationship between alcohol and blood pressure. 


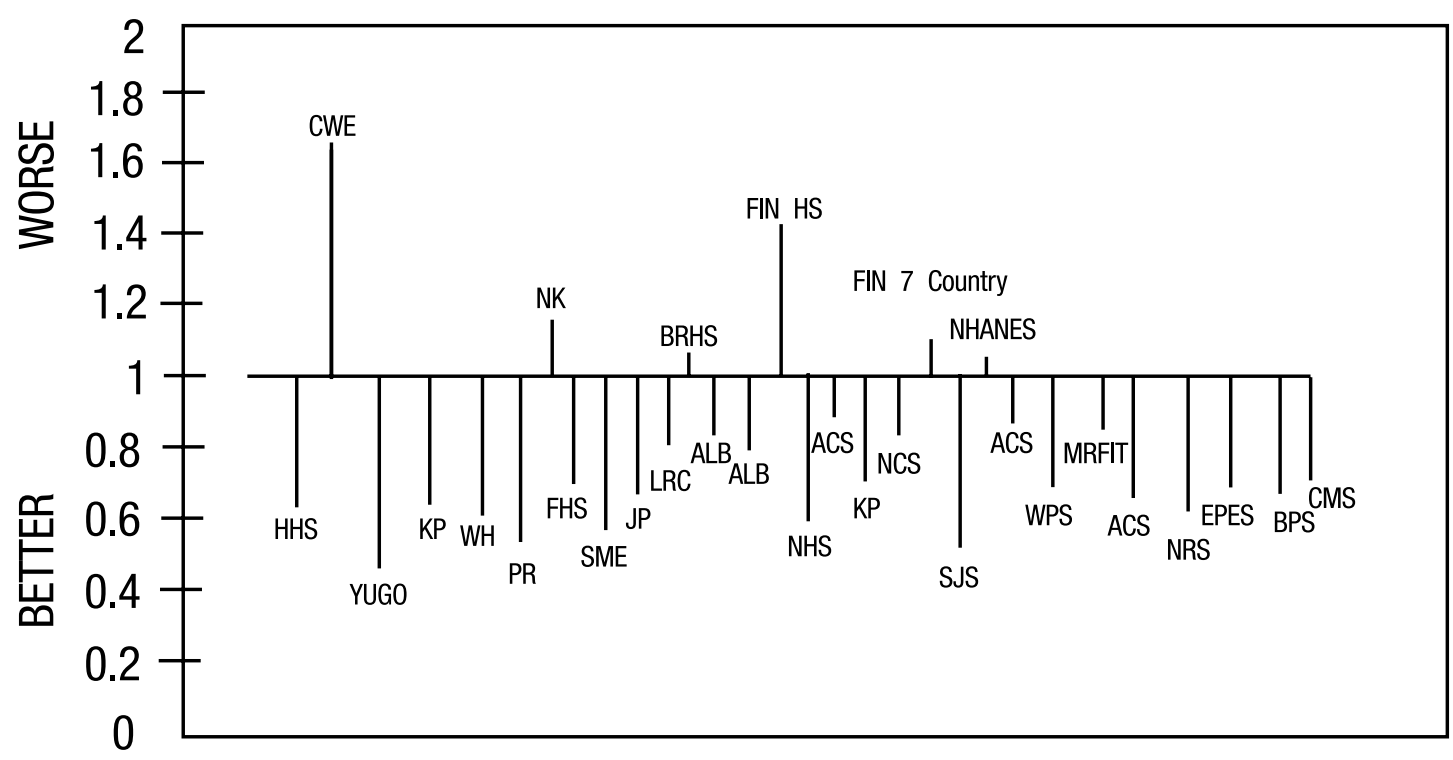

Fig. 1 - Cohort studies (1968-1993) of ethanol intake and coronary heart disease. Reading, left to right: HHS = Honolulu Heart Study; CWE = Chicago Western Electric Company Study; YUGO = Yugoslavia Cardiovascular Disease Study; KP = Kaiser Permanente matched cohorts study; WH = Whitehall Study; PR = Puerto Rico Heart Health Program; NK = North Karelia Project; FHS = Framingham Heart Study; SME = Study of Massachusetts Elderly; JP = Study of Japanese Physicians; LRC $=$ Lipid Research Clinics Follow-up Study; BRHS = British Regional Heart Study; ALB = Albany Study, 18- and 10- year follow up; FIN HS = Finnish Mobile Clinic Health Survey; NHS = Nurses`' Health Study; ACS = American Cancer Society Prospective Study, women; KP = Kaiser Permanente cohort study; NCS = Nutrition Canada Survey Cohort Study; FIN 7 Country = Finnish rural cohorts of the Seven Countries Study; SJS = St. James Survey; NHANES = NHANES 1 Epidemiologic Follow-up Study; ACS = American Cancer Society Prospective Study, men; WPS = Health Professionals Follow up Study; MRFIT = Multiple Risk Factor Intervention Trial; ACS = Alameda County Study; NRS = Normative Aging Study; EPES = Established Populations for Epidemiologic Study of the Elderly; BPS = Busselton Population Study; CMS = Copenhagen Male Study. Reproduced from MacLure M. 1993, by permission of Oxford University Press.

\section{MECHANISMS OF ACTION}

Alcohol consumption causes an increase of HDLcholesterol, due to increases in sub-fractions $\mathrm{HDL}^{2}$ and $\mathrm{HDL}^{3}$, and apoA-1 and apoA-2. Data from Framingham study corroborate evidences that alcohol increases HDL-cholesterol and it improves the ration total-cholesterol/HDL-cholesterol; there is a $10 \%$ risk reduction for DAC consequent to 0.1 $\mathrm{mmol} / \mathrm{l}$ increase in HDL-cholesterol (Kannel \& Ellison 1996, Golberg et al. 1999).

Alcohol does not affect LDL-cholesterol. However, there may be transient acute reductions when alcohol is taken with meals, especially during the first post-prandial 5 hours and is accompanied by HDL increases. However, in heavy drinkers, increased fasting serum Triglyceride and VLDLcholesterol were noted. Lp(a), other risk factor for $\mathrm{CAD}$, decreases in response to moderate alcohol intake. Also alcohol effects were documented in the coagulation system; inhibition of thromboxane production, reduction in platelet aggregation in animals as in humans, increases in plasminogen activators and reduction in fibrinogen concentration were observed. At the experimental level, alcohol upregu- 
lates the synthesis of tissue-type (t-PA) by cultured human vascular endothelial cells and urokinase-type (u-PA) plasminogem activators after rather brief exposure (30 min) accompanied by increased fibrinolitc activity.

Some alcoholic beverages have in their constitution protective agents against atherosclerosis such as flavonoids. These components have antioxidant properties and are potent free-radical scavengers. They are, therefore, likely to prevent endothelial damage. In vitro, they are also able to protect LDL against oxidation more effectively than the vitamins $\mathrm{A}$ and $\mathrm{E}$. These phenolics are present in significant concentrations in red wine, but not in white wine, and they induce vascular relaxation by mechanisms that are both dependent and independent of nitric oxide. Resveratrol, present in red wine, inhibits many of the cellular reactions associated with atherosclerosis and inflammation, such as endothelial expression of vascular adhesion molecules and release of cytokines from polymorphonuclear leukocytes.

Other mechanisms, such as inhibition of smooth muscle cells migration were shown in vitro. It is possible that the vasodilation provoked by alcohol induces an increase in peripheral glucose uptake in states of reduction of the peripheral homeostase of glucose and insulin. But, a protective effect of alcohol consumption does exist in coronary disease, similar among no diabetics and type 2 diabetics.

\section{HYPERTENSION}

Hypertension is an important risk factor and is influenced by the alcohol intake. Guillman and collaborators (Guillman et al. 1995) reported a J-shaped association of alcohol intake with blood pressure in young adults, with the lowest levels in those who consume one to two drinks per day. This hypotensive effect of low-moderate alcohol consumption on blood pressure is more significant among women than men. Thus, heavy alcohol intake is almost always associated with systemic hypertension, and hence shall be avoided.

\section{ADVERSE EFFECTS}

In individuals that consume alcohol in excess it is difficult to distinguish the effects of etanol by itself, from those of socioeconomic influences, cigarette smoking, drug abuse and diet. There is an association between alcohol consumption and increased left ventricular mass, in men but not in women, independently of the type of alcoholic beverages (Gronbaek et al. 1994). On the other hand, the prevalence and severity of the alcoholic cardiomyopathy is directly related to the extent of time and dose of alcohol used. In individuals that ingest excess alcohol, there is higher risk of coronary occlusion, arrhythmias, hepatic cirrhosis, upper gastrointestinal cancers, fetal alcohol syndrome, murders, sex crimes, traffic and industrial accidents, robberies, and psychosis.

\section{FINAL COMMENTS}

Alcohol is no treatment for atherosclerosis; but it doesn't need to be prohibited. In fact, in the absence of contra-indications, it may be beneficial under especific conditions. Probably, the most important effect of wine is due to flavonoids that are also present in the "healthy" diet. Thus moderate amounts of alcohol (1-2 drinks/day), especially red wine, may be allowed for those at risk for atherosclerosis complications.

\section{RESUMO}

A aterosclerose se manifesta como doença arterial coronária (DAC), acidente vascular cerebral e/ou doença vascular periférica. O consumo moderado de álcool tem sido associado com a redução de complicações da DAC. O vinho tinto parece fornecer maiores benefícios do que qualquer outro tipo de bebida alcoólica, provavelmente devido aos flavonóides. Os flavonóides induzem o relaxamento vascular por mecanismos tanto dependentes quanto independentes de óxido nítrico, inibem muitas das reações celulares associadas com aterosclerose e inflamação tais como a expressão endotelial de moléculas de adesão vascular e liberação de citocinas dos leucócitos polimorfonucleares.

A hipertensão é também influenciada pela ingestão de álcool. O consumo de doses elevadas de álcool está quase 
sempre associado à hipertensão sistêmica e, portanto, deve ser evitado. Em indivíduos que ingerem um excesso de álcool, há risco de oclusão vascular, arritmias, cirrose hepática, câncer gastro-intestinal, síndrome alcoólica fetal, assassinatos, crimes sexuais, acidentes industriais e de tráfico, roubos e psicose. O álcool não é um tratamento para a aterosclerose, mas, não precisa ser proibitivo. Em resumo, quantidades moderadas de vinho tinto (1-2 taças/dia), podem ser permitidas para aqueles em situação de risco pelas complicações da aterosclerose.

Palavras-chave: álcool, doença cardíaca coronária, aterosclerose, derrames, vinho tinto.

\section{REFERENCES}

Camargo CA JR, Hennekens CH, Gaziano JM, Glynn RJ, MNSON JE \& Stampfer MJ. 1997. Prospective study of moderate alcohol consuption and mortality in US male physicians. Arch Intern Med 1997 157: 79-85.

DA Luz PL, Serrano JR CV, Chacra AP, Monteiro HP, Yoshida VM, Furtado M, Ferreira S, GutierREZ P \& Pileggi F. 1999. The effect of red wine on experimental atherosclerosis: lipid-independent protection. Exp and Mol Pathol 65: 150-159.

Golberg DM, Soleas GJ \& Levesque M. 1999. Moderate Alcohol Consumption: The gentle face of Janus. Clin Biochem 32(7): 505-518.

Gordon T \& Kannel WB. 1983. Drinking habits and cardiovascular disease: The Framingham Study. Am Heart J 105: 667-673.
Gronbaek M, Deis A \& Sorensen TIA. 1994. Influence of sex, age, body mass index, and smoking on alcohol intake and mortality. Br Med J 308: 302-306.

Guillman MW, Cook NR, Evans DA, Rosner B \& HenNeKens CH. 1995. Relationship of alcohol intake with blood pressure in young adults. Hypertension 25: 1106-1110.

KAnNel WB \& Ellison RC. 1996. Alcohol and coronary disease: the evidence for a protective effect. Clin Chim Acta 246: 59-76.

Klatsky AL, Armstrong MA \& Friedman GD. 1990. Risk of cardiovascular mortality in alcohol drinkers, ex-drinkers and non-drinkers. Am J Cardiol 66: 1237-1242.

Lorgeril M, Salen P, Martin JL, Monjaud I, DeLAye J \& Mamelle N. 1999. Mediterranean diet, traditional risk factors, and the rate of cardiovascular complications after myocardial infarction. Circulation 99: 779-785.

MacLure M. 1993. Demonstration of deductive metaanalysis: ethanol intake and risk of myocardial infarction. Epidemiol Rev 124: 481-489.

Marmot M \& Brunner E. 1991. Alcohol and cardiovascular disease: The status of the U-shaped curve. BMJ 303: 565-568.

Stampfer MI, Colditz GA, Willet WC, Speizer FE \& HenNeKens CH. 1988. A prospective study of moderate alcohol consumption and the risk of coronary disease and stroke in women. NEJM 319: 267-273.

WAnNAmethee SG \& Shaper AG. 1998. Alcohol, coronary heart disease and stroke: an examination of the J-shaped curve. Neuroepidemiology 17: 288-295. 